\begin{tabular}{|c|c|}
\hline & $\begin{array}{c}\text { Omni-Akuatika Special Issue } 3^{\text {rd }} \text { Kripik SCiFiMaS 2020: } 26 \text { - } 32 \\
\text { ISSN: 1858-3873 print / 2476-9347 online }\end{array}$ \\
\hline & Research Article \\
\hline & journal homepage: http://ojs.omniakuatika.net \\
\hline
\end{tabular}

\title{
Shallow Water Seabed Profile Changes in 2016 - 2018 Based on Landsat 8 Satellite Imagery (Case Study: Semak Daun Island, Karya Island and Gosong Balik Layar)
}

\section{Zahra Safira Aulia, Triguardi Tharik Ahmad, Ratih Rachma Ayustina, Fauzi Tri Hastono, Rizqi Rizaldi Hidayat", Haji Mustakin, Agi Fitrianto, and Faras Bagus Rifanditya}

\author{
Department of Marine Science, Fisheries and Marine Science Faculty, Jenderal Soedirman University, \\ Purwokerto, Indonesia
}

*Corresponding author: rizqi.rizaldi@unsoed.ac.id

Received 20 November 2019; Accepted 1 October 2020; Available online 31 December 2020

\begin{abstract}
Seribu Islands is one of the marine tourism destinations in Jakarta. The high level of tourism in the Seribu Islands can be a threat to shallow water seabed profile habitat. Therefore, monitoring of changes in shallow water seabed profile habitat is needed so the sustainability can be monitored. This study aimed to determine changes in the shallow water seabed profile on Karya Island, Semak Daun Island, and Gosong Balik Layar in 2016 and 2018 based on Landsat 8 Satellite Imagery. Methods of this research used satellite image pre-processing, image classification, field survey, image reclassification, and accuracy assessment. The results showed that the coral area had decrease trend, while the area of Seagrass mix Seaweed had increased. The result of this classification had an accuracy value of $71.52 \%$
\end{abstract}

Keywords: remote sensing, multispectral imagery, Lyzenga, benthic habitat, Seribu Island

\begin{abstract}
ABSTRAK
Kepulauan Seribu merupakan salah satu destinasi wisata perairan di kota Jakarta. Tingginya tingkat pariwisata di Kepulauan Seribu dapat menjadi ancaman bagi habitat perairan dangkal. Untuk itu dibutuhkan pemantauan perubahan habitat dasar perairan agar kelestarian dapat tetap terpantau. Penelitian ini bertujuan untuk mengetahui perubahan profil dasar laut air dangkal di Pulau Karya, Pulau Semak Daun, dan Gosong Balik Layar pada tahun 2016 dan 2018 berdasarkan citra satelit Landsat 8. Metode penelitian ini meliputi pra-pemrosesan citra satelit, klasifikasi gambar, survei lapangan, klasifikasi ulang citra, dan penilaian akurasi. Hasil penelitian diperoleh bahwa luas penutupan terumbu karang mengalami penurunan, sedangkan luas campuran lamun rumput laut mengalami peningkatan. Hasil klasifikasi ini memiliki nilai akurasi $71,52 \%$.
\end{abstract}

Kata Kunci: penginderaan jauh, citra multispectral, lyzenga, habitat bentik, Kepulauan Seribu

\section{Introduction}

Indonesia is an archipelagic country that has the most natural resources, there are shallow-water habitats such as seagrass, algae, and coral reefs. According to Setyawan et al. (2014), shallow water is one of the areas which have high water dynamics and an important role both economically and ecologically. Therefore, the information regards the distribution of shallow water seabed profiles is important for further study. Through this information, the sustainability of the shallow water seabed profile ecosystem can be maintained properly.

However, according to Prayuda (2014), information about the distribution of shallow water seabed profiles in Indonesia's coastal area is still lacking, because the area is wide and unreachable. Therefore, there is a need for technology that can provide information about shallow water seabed profile effectively and 
efficiently. Remote sensing is a technology that can answer this problem. According to Lillesand and Kiefer (1999), remote sensing can record the surface of the earth that is unreachable and also provides the latest image data with different recording times and allowing to analysis for multi-time.

Utilization of Landsat 8 satellite imagery which has a multispectral image is very efficient to provide information on shallow water seabed profiles. Landsat 8 imagery has multitemporal properties that effective to see the differences in shallow water seabed profile over time. Utilization of satellite technology is considered more effective in terms of cost and time than conventional shallow water seabed profile mapping (Eugenio et al., 2015).

Landsat 8 imagery is the latest generation that substitutes Landsat 7 with Operational Land Imager (OLI) sensor and Thermal Infrared Sensor (TIRS) with 11 bands. In the previous generation of Landsat data, the gray level (Digital Number-DN) ranges from 0-256 while the Landsat 8 imagery data has a gray level of 0-4096. For Landsat 8 Imagery are has an increase in sensitivity, which at first each pixel has a quantification of 8 bits has now increased to 12 bits. This improvement makes the process of interpreting objects on the surface easier (USGS, 2015).

Seribu Island is determined as a marine protected area to promote and protect marine ecosystems. However, the ecosystem environment in Seribu Island continues to decline. The factors that are affected are domestic waste, ship traffic, industrial waste, and urban runoff from the Jakarta metropolitan city (Ranewa, 2008). Seribu Island is directly adjacent administrative to the Jakarta Bay where has a high risk of pollution was coming from the mainland and shipping activities around the Tanjung Priok port in Jakarta. Seribu Island is also a tourist spot visited by many people, this resulted in the degradation of shallow-water habitats such as seagrasses, algae, and coral reefs. Therefore, this study makes an attempt to determine the changes in shallow water seabed profile in 2016 and 2018 by applying Lyzenga Algorithm based on Landsat 8 Satellite Imagery.

\section{Materials and Methods}

\subsection{Time and Study Area}

This study was carried out in Seribu Island cluster that is Semak Daun Island, Karya Island, and Gosong Balik Layar Island from 5 to 8 August 2018. The location of this study was shown in Figure 1. Seribu Island is outside of Jakarta Bay and this sea-water is vulnerable to various pollution challenges because the location is directly related to the Jakarta Bay which is a place where 13 rivers flow through the densely populated and industrial city of Jakarta. The administrative district of Seribu Island has an area of about 1,180.80 Ha which
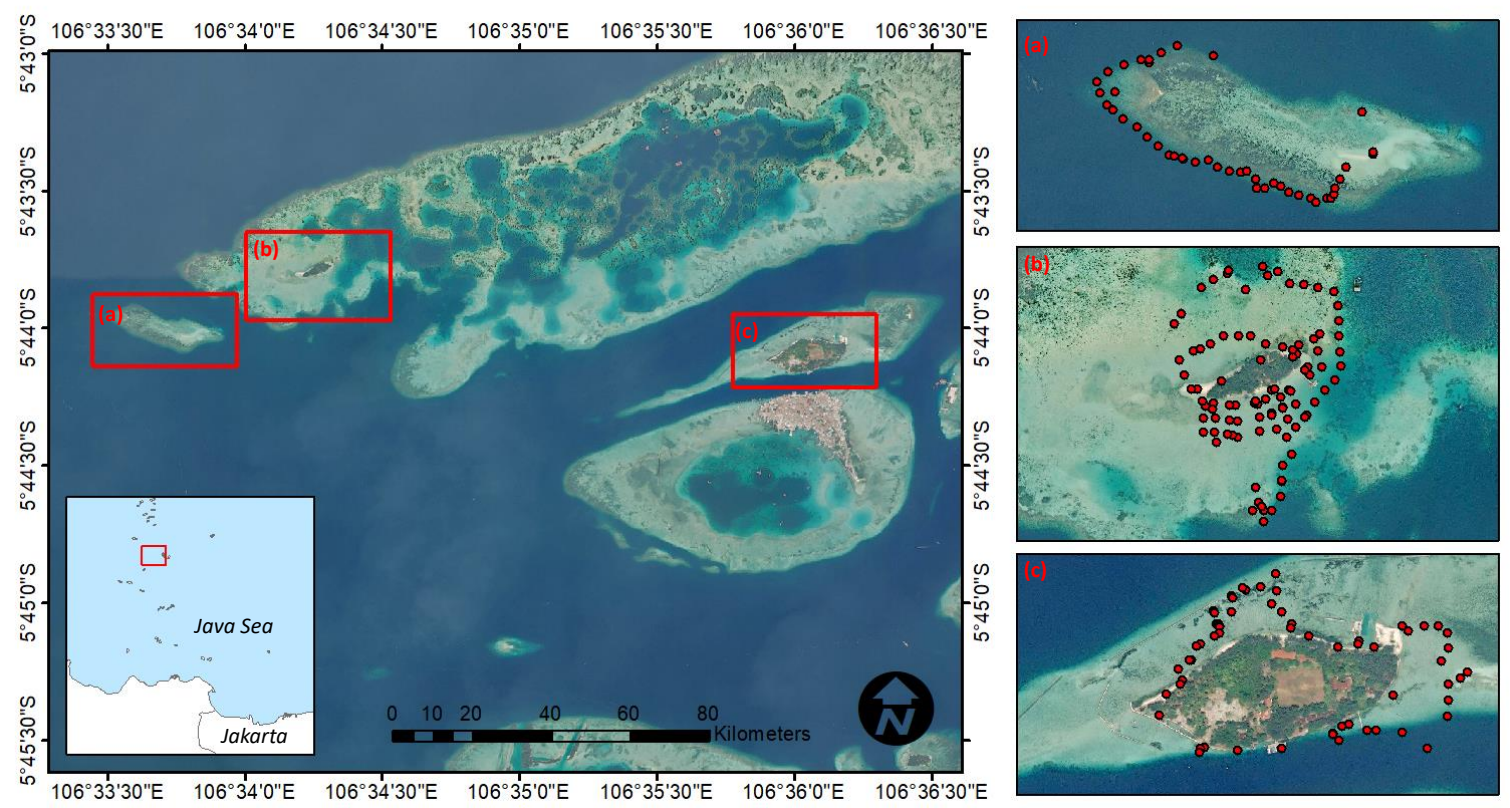

Figure 1. The research location consists of three clusters (a) Gosong Balik Layar, (b) Semak Daun Island, and (c) Karya Island. The red points indicate the location of the field survey used for classification and accuracy assessment. 
consists of an area of $6,997.5 \mathrm{~km}^{2}$ and a group of islands covering an area of 869.71 ha (Sachoemar, 2008). Seribu Island is dominated by the coral reef ecosystem, seagrass, and seaweed which are important habitats for various types of marine biota.

\subsection{Materials and Methods}

The satellite imagery data used in this study is Landsat 8 satellite imagery recorded on 13 May 2016 and 6 July 2018. Field data collection was carried out by identifying in situ substrate waters. The field data is then used as a classification and to determine Landsat 8 Satellite Imagery's in mapping shallow water seabed profile.

\subsection{Pre Survey Image Processing}

Pre-survey image processing consists of several stages, there are radiometric correction, cropping, masking, correction of water columns using lyzenga algorithm. Radiometric correction aims to improve the visual quality of images and improve pixel values that do not correspond to the actual spectral reflection of objects. This is due to an error in the optical system, interference with electromagnetic radiation energy in the atmosphere and the influence of the sun's elevation angle (Purwadhi et al., 2015). Radiometric correction is carried out by performing from correction of radiant and correction of reflectance. The transmission corrections made are:

where :

$$
L \lambda^{\prime}=L Q c a l+A L
$$

$L \lambda^{\prime} \quad$ : value of radian spectral $\left(\mathrm{W} / \mathrm{m}^{2} \mathrm{str} \mu \mathrm{m}\right)$

Qcal : digital number

$M L \quad$ : constant of rescaling

$A_{L} \quad$ : constant of adders

Correction of reflectance using formula :

$$
\rho \lambda^{\prime}=\rho Q \operatorname{cal}+A \rho / \operatorname{Cos}(\theta \mathbf{s})
$$

where:

$\rho \lambda^{\prime} \quad$ : value of processing without the retrieval correction

Qcal : digital number

$\mathrm{M} \rho \quad$ : constant of rescaling

A $\rho$ : constant of adders

$\operatorname{Cos}(\theta s)$ : value of sun zenith angle

Cropping of image is done to focus image processing in one area, according to the study area. While masking aims to split land and water. So, the research focused on shallow waters only. If the land and waters are not separated, the image pixels in the mainland area will interfere with the interpretation of the image in the next process (Prayuda, 2014).
Water column correction is done by sharpening the image to see the classification of shallow water seabed objects using the channel transformation approach, namely the Depth Invariant Index (DII) algorithm (Lyzenga, 2978). Bands used in this algorithm are band 2 and band 3 . Bands 2 and band 3 have good penetration in shallow water, so as to be able to map the shallow water seabed profile properly (Mount, 2006). The Lyzenga algorithm used according to BIG (2014) are :

$$
\begin{aligned}
Y= & (\text { In Band } 1-\text { Band } 1 \text { Deep })-\frac{k i}{k j} * \\
& (\text { In Band } 2-\text { Band } 2 \text { Deep }) \ldots \ldots \ldots . . .(3)
\end{aligned}
$$
where:

$Y \quad$ : value of lyzenga

In (Band1) : logarithm of blue band

$(\mathrm{ki} / \mathrm{kj}) \quad$ : value of the Var and Cov on blue and green bands

In (Band2) : logarithm of green band

Band Deep : value of the band in the depth of the sea

\subsection{Field Survey}

The field survey was carried out on 05 - 08 August 2018 on Semak Daun Island, Karya Island, and Gosong Balik Layar Island. The stage of the field survey conducted in this study included observing objects at the study site. The objects observed were coral reefs, seagrasses, macroalgae, and basic substrates. Field data retrieval is done by assigning the points of control that are considered to have indicated object based on variations in the conditions of the waters processed by true-color satellite imagery (Wicaksono, 2014). Field data was conjugated by Rapid Reef Assessment (RRA) technique to receive large-scale shallow water seabed objects (Dahlan, 2014). Shallow seabed object collection is done by photographing objects in the field once every 15 meters continually, because Landsat 8 imagery has 30 meters spatial resolution (USGS, 2016. Observation of objects at the time of the survey was conducted using direct observation by snorkeling and the position of the observation point was recorded using Global Positioning System (GPS).

Sampling data in the field was obtained 204 points (Figure 1). Which 102 points are used to make the classification of shallow water profiles and 102 points are used for accuracy assessment? In Gosong Balik Layar Island, 45 points were obtained, Semak Daun Island 98 points, and Karya Island 61 points. 

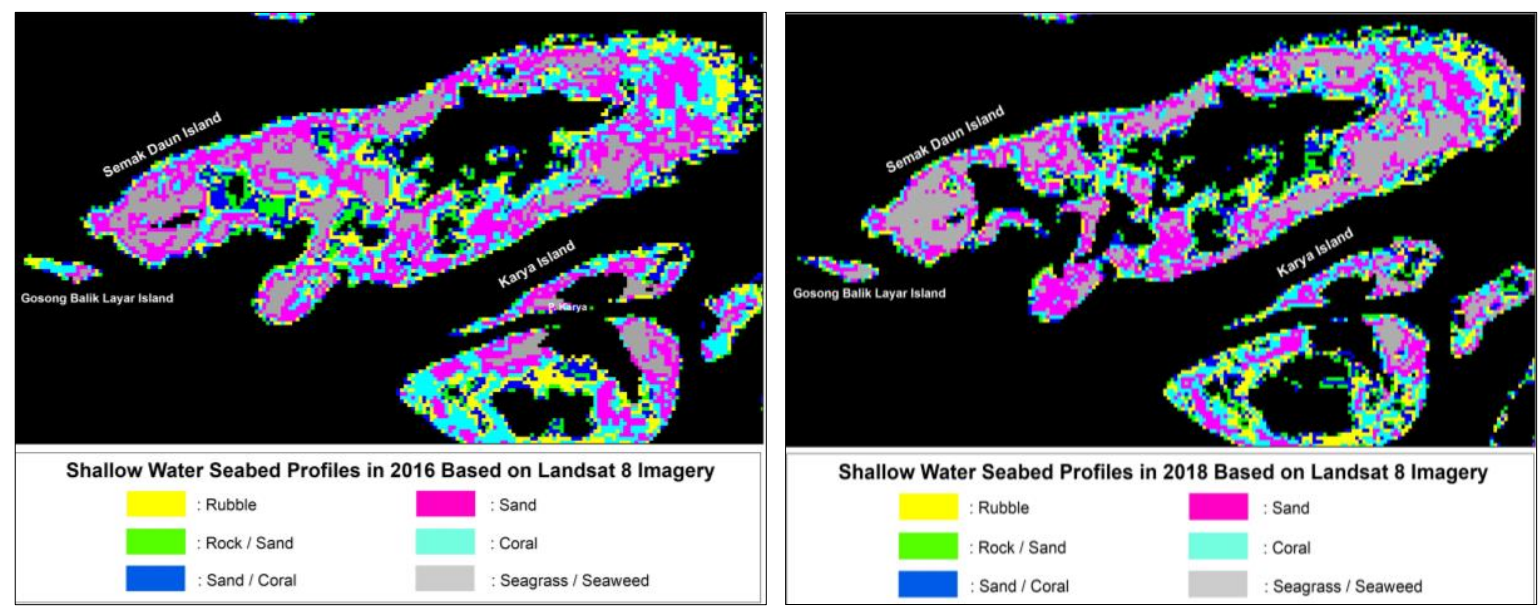

Figure 2. Shallow water habitat classification results in 2016 and 2018.

\subsection{Image Classification}

The classification process is carried out using data that has been obtained in the field. The data obtained were divided into two sections, there are the data used for classification and accuracy assessment. The image is classified as supervised according to the field observation data using the maximum likelihood algorithm. Classification of satellite imagery in this way has been widely used to produce maps of coral reef areas (Andrëfouet et al., 2003).

\subsection{Accuracy Assessment}

The accuracy assessment is carried out using data that has been obtained in the field. This assessment is very important to get a reliable map. The accuracy test used is using an error matrix. This is done by comparing the classes on the map against the actual classes from the field survey (Congalton and Green, 1999). According to Congalton and Green (1999), from the confusion matrix table and formula calculations, overall accuracy is obtained where percentage of number of objects that correspond to the overall object classification results (results from satellite imagery) and reference data (results from field sampling). Then, the producer's accuracy aims to measure the estimation of the possibility of an object is classified as a class. Finally, the user accuracy aims to measure how well the image classification results are compared to the results of reference classification (field data).

\section{Result and Discussion}

3.1. Mapping of shallow water profile in 2016 and 2018

Classification of shallow water seabed profiles is based on survey data in the field. OLI Landsat-8 imagery can distinguish benthic habitat variations beyond 4 predefined classes. Landsat 8 satellite imagery can differentiate shallow water seabed profiles habitats variations in more than 4 classes, this is due to the support of high radiometric resolution (16bit) (Hafizt et al., 2017). The classes that can be built in this study amounted to 6 classes, namely: Rock / Sand (a combination of rock and sand dominated by rocks), Rubble, Sand / Coral (a combination of sand and live coral dominated by sand), Sand, Coral, Seagrass / Seaweed (a combination of seagrass and macroalgae dominated by seagrass). Based on image processing in 2016 and 2018 there are differences in the extent of the shallow water profiles in 2016 and 2018 (Figure 2). Research conducted by Makailipessy \& Souisa (2015) can produce 5 classes using Landsat 8 , those were sand, sand mixed coral, dead coral, coral reef, and seagrass. Hafizt et al. (2017) can produce 7 classes using Landsat 8, those were hard coral, dead coral mixed sand, sand mixed algae, sand mixed dead coral, seagrass mixed algae, sand, and seagrass.

\subsection{Comparison of Shallow Water Seabed Profiles Area in 2016 and 2018}

From 2016 to 2018 shallow water seabed profile areas in Semak Daun Island, Karya Island, and Gosong Balik Layar Island have changed (Table 1). Based on the measurement of the area, it is obtained that the area of the 
Coral Reef tends to decrease, while the area of the Seagrass mix Seaweed has increased on the three islands. The main factor that caused changes in the shallow water seabed profile are oceanographic conditions and also the increased tourism activity in Seribu Island. Siregar et al., (2020) conducted a study on the same location to obtain results that Coral Reef and Sand tends to decrease from 2008 to 2018, while the area of Dead Coral and Seagrass has increased.

From 2016 to 2018 the Coral Reef area in Semak Daun has decreased from 90.72 ha to 74.7 ha. Based on research conducted by Siregar et al. (2020), the area of Coral Reef in Semak Daun Island has decreased from 2008 to 2018. The decreasing area of coral reefs is caused by human activities. Semak Daun Island is an island that is often visited for recreational purposes. The average visit on Semak Daun Island is 166 people/day. The activities are usually carried out by visitors on Semak Daun Island are recreational activities in the form of snorkeling/swimming, capturing marine life, fishing, walking in shallow water, and camping. These activities can cause coral damage.

Karya Island is part of the Thousand Islands. Karya Island is often visited mainly by people because the sectoral police station and the Thousand Islands burial site are found on Karya Island. The frequency of visits from islanders to the island also disrupts the coral reef ecosystem. From 2016 to 2018 there was no change in the area of coral cover. Even so, the sustainability of coral reef ecosystems must still be maintained. According to Alamsyah et al.

Table 1. Seabed profile classification in Semak Daun Island

\begin{tabular}{lll}
\hline Classification & Area in 2016 (ha) & Area in 2018 (ha) \\
\hline Semak Daun Island & & \\
Rock / Sand & 36.54 & 34.56 \\
Sand / Coral & 57.4 & 45 \\
Rubble & 57.51 & 64.71 \\
Coral & 90.72 & 74.7 \\
Sand & 180 & 34.56 \\
Seagrass / Seaweed & 90.99 & 110.16 \\
\hline Karya Island & & \\
Rock / Sand & 3.87 & 4.14 \\
Sand / Coral & 4.68 & 7.11 \\
Rubble & 2.34 & 8.37 \\
Coral & 13.5 & 13.5 \\
Sand & 11.16 & 13.32 \\
Seagrass / Seaweed & 7.29 & 6.93 \\
\hline Semak Daun Island & & \\
Rock / Sand & 0.18 & 1.35 \\
Sand / Coral & 0.54 & 1.44 \\
Rubble & 1.8 & 1.35 \\
Coral & 2.07 & 1.53 \\
Sand & 2.43 & 3.33 \\
Seagrass / Seaweed & 1.17 & 1.75 \\
\hline
\end{tabular}

Table 2. Assesment Accuration of Shallow Water Seabed Profile Based on Landsat 8

\begin{tabular}{lrrrrrrrr}
\hline Survey & $\begin{array}{l}\text { Rock / } \\
\text { Sand }\end{array}$ & $\begin{array}{l}\text { Sand / } \\
\text { Coral }\end{array}$ & Rubble & Coral & Sand & $\begin{array}{l}\text { Seagrass / } \\
\text { Seaweed }\end{array}$ & $\begin{array}{l}\text { User } \\
\text { Accuracy }\end{array}$ \\
\hline Rock / Sand & 7 & 0 & 1 & 0 & 0 & 1 & $\mathbf{7 7 . 7 7}$ \\
Sand / Coral & 0 & 8 & 0 & 1 & 2 & 2 & $\mathbf{6 1 . 5 3}$ \\
Rubble & 1 & 0 & 13 & 2 & 1 & 1 & $\mathbf{7 2 . 2 2}$ \\
Coral & 0 & 2 & 2 & 11 & 0 & 0 & $\mathbf{7 3 . 3 3}$ \\
Sand & 1 & 1 & 3 & 2 & 17 & 1 & 60 \\
Seagrass / & 0 & 0 & 1 & 0 & 1 & 20 & $\mathbf{9 0 . 9 0}$ \\
Seaweed & $\mathbf{7 7 . 7 7}$ & $\mathbf{6 6 . 6 6}$ & $\mathbf{5 4 . 1 6}$ & $\mathbf{6 6 . 6 6}$ & $\mathbf{7 8 . 9 4}$ & $\mathbf{7 8 . 2 6}$ & \\
\hline $\begin{array}{l}\text { Producer } \\
\text { Accuracy (\%) }\end{array}$ & & & & & & & $\mathbf{7 1 . 5 2}$ \\
\hline $\begin{array}{l}\text { Overall (\%) } \\
\text { Accuracy (\%) }\end{array}$ & & & & & & & &
\end{tabular}


(2019), Karya Island is very vulnerable to human activities that have an impact on damage. Damage can be in the form of coral fragments which are generally overgrown by mosses due to being exposed to ship anchors.

The coral reef ecosystem in Gosong Balik Layar Island has the best condition when compared to Semak Daun Island and Karya Island. However, the area of coral reefs in the Semak Daun Island has decreased. This decrease is caused by the reef is often hit by ships. During the survey in the field, many corals were scratched and broken because they were hit by a ship.

\subsection{Accuracy Assessment}

Accuracy assessment is done by using two measurements, namely the survey results and image classification arranged in a twodimensional matrix (confusion matrix). The results of the accuracy calculation can be seen from Overall Accuracy (OA), Producer Accuracy (PA), and User Accuracy (UA). Field data used for accuracy assessment were 102 sample points. The accuracy assessment results with the "matrix confusion" are presented in Table 2 with the overall accuracy (OA) value obtained is $71.52 \%$. The accuracy assessment results included meeting the accuracy-test value standard because it has a value of $\geq 70 \%$ (Purwadhi, 2001). Meanwhile, according to Green et al. (2000), the accuracy of mapping shallow water seabed profiles that can be used is with an overall accuracy of $>60 \%$.

Based on the measurement of the area, it is obtained that the area of the Coral Reef tends to decrease, while the area of the Seagrass mix Seaweed has increased on the three islands. Changes in the area of the shallow water seabed profile show that the area whose reduction does not disappear but is replaced by the extent of other habitats. Field observations indicate that the decline in coral reef habitat is a result of human activity, this can be seen from the rubble. Coral reef ecosystems are very vulnerable to human and environmental disturbances so that they are easily damaged (Farid et al., 2018). Physical destruction of reefs by fish bombing, cyanide fishing, coral mining, and dredging leads to the destruction of coral reefs ecosystems. The increasing number of tourists is also a factor in the decline in the value of coral reefs. Many websites describe that Seribu Island is the best place for diving, snorkeling, trekking, jogging, and birding. It is said that Seribu Island becomes one of the favorites and first choice of tourism destination among Jakarta's dweller to seek clean and unpolluted areas. If the coral reef is damaged, the social and economic conditions of the community will decline. This is because some of the population in the Seribu Islands work as fishermen and coral reefs have a function as a habitat for fish and other marine organisms. Therefore, efforts should be made to prevent the decline of coral reefs. Small islands are reflecting dynamic entities that continually changing according to environmental conditions, they should be driven in sustainable development vision to achieve economic growth and nature conservation in balance (Hakim et al., 2007).

\section{Conclusion}

Mapping of the shallow water seabed profiles on Karya Island, Semak Daun Island, and Gosong Balik Layar Island using Landsat 8 Satellite Imagery can produce 6 classes, namely Rock / Sand (a combination of rock and sand dominated by rock), Rubble, Sand / Coral (a combination of sand and coral dominated by sand), Sand, Coral, Seagrass / Seaweed (a combination of seagrass and macroalgae dominated by seagrass). The area of the Coral Reef tends to decrease while the area of Seagrass / Seaweed and Rubble has increased. This research has an accuracy of $71.52 \%$, and it can be used because it has a value of $\geq 70 \%$.

\section{Acknowledgments}

We would like to thanks our members of Team Ekspedisi IV HIMAKEL for providing help with field work. This work was supported by Risearch and Technology of Himpunan Mahasiswa IImu Kelautan, Universitas Jenderal Soedirman.

\section{References}

Alamsyah, R., Uspar, Armita, P., Nurfadillah. 2019. Sebaran dan Luasan Terumbu Karang di Perairan Pulau Larearea Menggunakan Citra Landsat 8. Jurnal Agrominansia 4: 2527-4358.

Andrëfouet, S., Kramer, P., Pulliza, T. D., Joyce, E. K., Hochberg, J. E., Perez, G. R., Mumby, J. P., Riegl, B., Yamano, H., White, H. W., Zubia, M., Brock, C. J., Phinn, R. S., Naseer, A., Hatcher, G. B., Muller, K. E. F. 2003. Multi-site evaluation of IKONOS data for classification of tropical coral reef environments. Remote Sensing of Environment 88: 128-143. 
Badan Informasi Geospasial (BIG). 2014. Pengumpulan dan Pengolahan Data Geospasial Habitat Dasar Perairan Laut Dangkal. Badan Informasi Geospasial, Cibinong.

Congalton, R. G., Green, K. 1999. Assessing the Accuracy of Remotely Sensed Data: Principles and Practices. Lewis Publisher, Boca Rotan. 137 pp

Dahlan. 2014. Penilaian Ekosistem Terumbu Karang di Kepulauan Aruri Kabupaten Supiori. Journal of Fisheries Development 1: 61-82.

Eugenio, F., Marcello, J., Martin, J. 2015. HighResolution Maps of Bathymetry and Benthic Habitats in Shallow-Water Environments Using Multispectral Remote Sensing Imagery. IEEE Transactions on Geoscience and Remote Sensing 53(7): 3539-3549.

Purwadhi, F. S. H., Haryani, N. S., Rokhmatuloh, Kardono, P., Kasidi, A. 2015. Aplikasi Penginderaan Jauh dan Sistem Informasi Geografis untuk Pengembangan Wilayah. Polimedia Publishing, Jakarta. 491 pp.

Farid, M., Pujiono, W. P., Supriharyono. 2018. Perubahan Tutupan Terumbu Karang Ditinjau dari Banyaknya Wisatawan di Tanjung Gelam Kepulauan Karimunjawa Menggunakan Citra Satelit Landsat 8 Oli. Journal of Maquares 7: 18-27.

Green, E. P., Mumby, P. J., Edwards, A. J., Clark, C. D. 2000. Remote Sensing Handbook for Tropical Coastal Management. Unesco Publishing, Paris.

Hafizt, M., Iswari, M. Y., Prayudha, B. 2017. Assessment of Landsat-8 Classification Method for Benthic Habitat Mapping in Padaido Islands. Papua Oseanologi dan Limnologi di Indonesia 2: 1-13

Hakim, L., Hong, S. K., Kim, J. E., Nakagoshi, N. 2007. Nature-based Tourism in Small Islands Adjacent to Jakarta City, Indonesia: A case study from Seribu Islands. Journal of the Korean Wetlands Society 9: 31-46

Lillesand dan Kiefer. 1999. Penginderaan Jauh dan Interpretasi Citra. Gadjah Mada University Press, Yogyakarta.
Lyzenga, D. R. 1978. Passive Remote-Sensing Technique for Mapping Water Depth and Bottom Features. Applied Optics 17: 379383.

Makailipessy, M. M. Souisa, F. 2015. Pemetaan Substrat Dasar Perairan Dangkal di Kecamatan Tayando Kota Tual Menggunakan Citra Landsat 8. Neritic 6: 1-6.

Mount, R. E. 2006. Acquisition of Through Water Aerial Survey Images: Surface Effects and the Prediction of Sun Glitter and Subsurface Illumination. Photogrammetric Engineering and Remote Sensing 71: 1407-1415.

Prayuda, B. 2014. Panduan Teknis Pemetaan Habitat Dasar Perairan Laut Dangkal. CRITC COREMAP II LIPI, Jakarta. 21 pp.

Purwadhi, F. S. H. 2001. Interpretasi Citra Digital. PT. Grasindo, Jakarta.

Ranema, W. 2008. Habitat Selective Factors Influencing the Distribution of Larger Benthic Foraminiferal Assemblages Over the Kepulauan Seribu. Marine Micropaleontology 68: 286-298.

Setyawan, I. E., Siregar, V. P., Pramono, G. H., Yuwono, D. M. 2014. Pemetaan Profil Habitat Dasar Perairan Dangkal Berdasarkan Bentuk Topografi: Studi Kasus Pulau Panggang, Kepulauan Seribu Jakarta. Majalah Ilmiah Globe 16: 125-132.

Siregar, V. P., Agus, S. B., Sunuddin, A., Subarno, T., Aziizah, N. N. 2020. Analisis Perubahan Habitat Dasar Perairan Dangkal Menggunakan Citra Satelit Resolusi Tinggi di Karang Lebar, Kepulauan Seribu. Jurnal IImu dan Teknologi Kelautan Tropis 12: 37-51.

USGS. 2015. Landsat 8 (L8) Data Users Handbook. Department of the Interior U.S: U.S. Geological Survey.

USGS. 2016. Landsat 8 (L8) Data Users Handbook. Department of the Interior U.S: U.S. Geological Survey.

Wicaksono, P. 2014. The use of Image Rotations on Multispectral-based Benthic Habitats Mapping. 12th Biennial Conference of Pan Oceanic Remote Sensing Conference, Bali. 